\section{Different priming techniques, including mivacurium, accelerate the onset of rocuronium}

Mohamed Naguib MB BCh MSc FFARCSI MD
Different priming sequences of equipotent doses of rocuronium and mivacurium on the onset of maximum neuromuscular block and intubating conditions were compared with those obtained after succinylcholine. During thiopentone-fentanylnitrous oxide anaesthesia, 70 patients were randomly assigned into seven groups. Group I received mivacurium $0.15 \mathrm{mg} \cdot \mathrm{kg}^{-1}$ as a single bolus dose. Group II received a priming dose of mivacurium $0.015 \mathrm{mg} \cdot \mathrm{kg}^{-1}$ followed three minutes later by mivacurium $0.135 \mathrm{mg} \cdot \mathrm{kg}^{-1}$. Group III received rocuronium $0.6 \mathrm{mg} \cdot \mathrm{kg}^{-1}$ as a single bolus dose, and Group IV received an initial dose of rocuronium $0.06 \mathrm{mg} \cdot \mathrm{kg}^{-1}$ followed by rocuronium $0.54 \mathrm{mg} \cdot \mathrm{kg}^{-1}$. Group $V$ received a priming dose of mivacurium $0.015 \mathrm{mg} \cdot \mathrm{kg}^{-1}$ followed by rocuronium 0.54 $\mathrm{mg} \cdot \mathrm{kg}^{-1}$. Group VT received an initial dose of rocuronium $0.06 \mathrm{mg} \cdot \mathrm{kg}^{-1}$ followed by mivacurium $0.135 \mathrm{mg} \cdot \mathrm{kg}^{-1}$. Group VII received succinylcholine $1.0 \mathrm{mg} \cdot \mathrm{kg}^{-1}$. Groups $I$, III, and VII received a placebo injection before the administration of the neuromuscular blocking drug. Additional thiopentone 2 $\mathrm{mg} \cdot \mathrm{kg}^{-1}$ iv was given $30 \mathrm{sec}$ before intubation. Onset times (mean (95\% confidence interval)) afier priming a rocuronium block with either rocuronium (73 (57-90) sec) or mivacurium (58 (47-69) sec) were similar to those after succinylcholine (54 $(40-68)$ sec), and were shorter $(P<0.01)$ than that observed in other groups. Intubating conditions were not different between the groups. The duration of neuromuscular block was shortest with succinylcholine. It is concluded that priming a rocuronium block with either mivacurium or rocuronium resulted in a neuromuscular block comparable to that of suc-

\section{Key words}

INTERACTIONS: mivacurium, rocuronium (ORG 9426); MONITORING: train-of-four;

NEUROMUSCULAR RELAXANTS: mivacurium, rocuronium, succinylcholine;

PHARMACODYNAMICS: priming principle.

From the Department of Anaesthesia and ICU, King Saud University, and Faculty of Medicine at King Khalid University Hospital, PO Box 7805, Riyadh 11472, Saudi Arabia. Address correspondence to: Dr. M. Naguib. Accepted for publication 9 th Jume, 1994. cinylcholine in both the onset of action and intubating conditions.

Cette étude compare l'influence de différentes séquences d'amorşage avec des doses d'égale puissance de rocuronium et de mivacurium sur le début du bloc neuromusculaire complet et les conditions dintubation avec celles de la succinylcholine. Pendant une anesthésie au thiopentone-fentanyl-protoxyde d'azote, 70 patients sont assignés au hasard entre sept groupes. Le groupe I reçoit un seul bolus de mivacurium $0,15 \mathrm{mg} \cdot \mathrm{kg}^{-1}$. Le groupe II reçoit une dose d'amorce de mivacurium 0,015 $\mathrm{mg} \cdot \mathrm{kg}^{-1}$ suivie trois minutes plus tard de mivacurium 0,135 $m g \cdot \mathrm{kg}^{-1}$. Le groupe III reçoit un seul bolus de rocuronium $0,6 \mathrm{mg} \cdot \mathrm{kg}^{-1}$. Le groupe IV reçoit une dose initiale de 0,06 $\mathrm{mg} \cdot \mathrm{kg}^{-l}$ de rocuronium suivie de rocuronium $0,54 \mathrm{mg} \cdot \mathrm{kg}^{-1}$. Le groupe $V$ reçoit une dose initiale de mivacurium 0,015 $\mathrm{mg} \cdot \mathrm{kg}^{-1}$ suivie de rocuronium $0,54 \mathrm{mg} \cdot \mathrm{kg}^{-1}$. Le groupe $V T$ reçoit une dose initiale de rocuronium $0,06 \mathrm{mg} \cdot \mathrm{kg}^{-1}$ suivie par mivacurium $0,135 \mathrm{mg} \cdot \mathrm{kg}^{-1}$. Le groupe VII reçoit succinylcholine $1,0 \mathrm{mg} \cdot \mathrm{kg}^{-1}$. Les groupes I, III et VII reçoivent un placébo en injection avant le myorelaxant. Un supplément de thiopentone $2 \mathrm{mg} \cdot \mathrm{kg}^{-1}$ iv est administré 30 sec avant l'intubation. Le début d'action (moyenne (intervalle de confiance 95\%)) après l'amorçage du bloc au rocuronium (73 (57-90) sec) ou au mivacurium ( $58(47-69) \mathrm{sec}$ ) est identique à celui qui suit la succinylcholine (54 (40-68) sec) et est plus court $(P<0,01)$ que celui qui est observé dans les autres groupes. Les conditions d'intubation ne different pas entre les groupes. Le bloc neuromusculaire le plus court est obtenu avec la succinylcholine. En conclusion, l'amorçage du bloc neuromusculaire avec soit le mivacurium soit le rocuronium produit un bloc comparable à celui de la succinylcholine tant pour le début d'action que pour les conditions d'intubation.

Succinylcholine continues to be the relaxant of choice where there is a need for rapid tracheal intubation as it consistently provides muscle relaxation within 60 to $90 \mathrm{sec}$. When succinylcholine is considered undesirable or contra-indicated, the onset of nondepolarizing neuromuscular blocking drugs can be accelerated by the use of high doses of an individual agent ${ }^{1,2}$ or combinations 
of relaxants ${ }^{3}$ or by preceding the intubating dose with a priming dose of relaxant. ${ }^{4-6}$ The high-dose regimens of nondepolarizing neuromuscular blocking drugs, however, have not consistently achieved the rapid onset of succinylcholine and were associated with considerable prolongation of the duration of action. ${ }^{1,2}$ Although some combinations of mivacurium and rocuronium can achieve rapid onset without undue prolongation of action and without undesirable effects, ${ }^{7}$ combination therapy was not reliable in achieving rapid onset consistently. ${ }^{3}$ Priming, on the other hand, can accelerate the onset of neuromuscular blockade but, after priming, intubating conditions do not match those after succinylcholine. ${ }^{8}$

Intubating conditions depend on many factors, the most important of which are the degree of relaxation of the muscle groups involved, the depth of anaesthesia, the anatomy of the upper airways and the skill of the anaesthetist. The superior intubating conditions associated with succinylcholine may lie not as much in its rapid onset but may because it has a greater potency at the laryngeal muscles than nondepolarizing neuromuscular blocking drugs. ${ }^{9}$ Further, Naguib et al. ${ }^{10}$ have demonstrated that the priming technique can be made to provide better conditions for tracheal intubation in $<90 \mathrm{sec}$. They noted that administration of $2 \mathrm{mg} \cdot \mathrm{kg}^{-1}$ thiopentone before injection of the intubating dose resulted in improvement of intubating conditions, probably due to the increase in the depth of anaesthesia. ${ }^{10}$

Rocuronium bromide and mivacurium chloride are nondepolarizing neuromuscular blocking agents that have recently been introduced to clinical practice. ${ }^{11,12}$ Mivacurium has a considerably shorter duration of action than any other currently used nondepolarizing agent. ${ }^{11}$ Rocuronium, on the other hand, has a brief onset but an intermediate duration of action. ${ }^{12}$ Because the onset of action of rocuronium is more rapid than that of other nondepolarizing muscle relaxants it may prove to be the muscle relaxant of choice with the priming technique. However, we are not aware of any study that has evaluated different priming techniques with rocuronium.

The purpose of this study was to compare the onset time of neuromuscular blockade, tracheal intubating conditions, and neuromuscular recovery following different priming techniques with equipotent doses of rocuronium and mivacurium, with that produced by succinylcholine.

\section{Methods}

After obtaining institutional approval and informed consent, 70 ASA physical status I or II patients were studied. All patients were undergoing elective procedures, had no neuromuscular, hepatic or renal disease, were not suspected of presenting difficulty with tracheal intubation, and were not taking any drug known or suspected to interfere with neuromuscular function.

No premedication was administered. An infusion of lactated Ringer's solution was given $i v$ before induction of anaesthesia. Pulse oximetry, ECG, and arterial blood pressure were monitored. Temperature was monitored by a nasopharyngeal thermistor and maintained at $36.5 \pm$ $0.5^{\circ} \mathrm{C}$.

Anaesthesia was induced with midazolam 0.03 $\mathrm{mg} \cdot \mathrm{kg}^{-1} i \mathrm{v}$ followed two to three minutes later by thiopentone 5-7 mg $\mathrm{kg}^{-1}$ and was maintained with $\mathrm{N}_{2} \mathrm{O}$ and $\mathrm{O}_{2}(70: 30)$ and incremental doses of fentanyl. Following loss of consciousness, the ulnar nerve was stimulated supramaximally at the wrist with square pulses of $0.2 \mathrm{msec}$ duration, delivered in a train-of-four (TOF) sequence at $2 \mathrm{~Hz}$ every $12 \mathrm{sec}$, using a Myotest peripheral nerve stimulator (Biometer International, Odense, Denmark). The resultant contraction of the adductor pollicis muscle was recorded using a force displacement transducer and neuromuscular function analyzer (Myograph 2000, Biometer International, Odense, Denmark). Preload tension on the thumb was maintained at $300 \mathrm{~g}$ throughout the investigation. The first twitch $\left(\mathrm{T}_{1}\right)$ of the TOF was considered the twitch height.

Once a steady state twitch was established, patients were assigned randomly to one of seven groups ( $n=$ ten in each). Patients in Group I received mivacurium $0.15 \mathrm{mg} \cdot \mathrm{kg}^{-1}$ as a single bolus dose, whereas those in Group II received an initial (priming) dose of mivacurium $0.015 \mathrm{mg} \cdot \mathrm{kg}^{-1}$ followed three minutes later by mivacurium $0.135 \mathrm{mg} \cdot \mathrm{kg}^{-1}$. Group III received rocuronium $0.6 \mathrm{mg} \cdot \mathrm{kg}^{-1}$ as a single bolus dose, and Group IV received an initial dose of rocuronium $0.06 \mathrm{mg} \cdot \mathrm{kg}^{-1}$ followed three minutes later by rocuronium $0.54 \mathrm{mg} \cdot \mathrm{kg}^{-1}$. Patients in Group V received an initial dose of mivacurium $0.015 \mathrm{mg} \cdot \mathrm{kg}^{-1}$ followed three minutes later by rocuronium $0.54 \mathrm{mg} \cdot \mathrm{kg}^{-1}$. Group VI received an initial dose of rocuronium $0.06 \mathrm{mg} \cdot \mathrm{kg}^{-1}$ followed three minutes later by mivacurium $0.135 \mathrm{mg} \cdot \mathrm{kg}^{-1}$. Group VII (controls) received succinylcholine $1.0 \mathrm{mg} \cdot \mathrm{kg}^{-1}$. Patients in Groups I, III, and VII received a saline placebo injection three minutes before the administration of the neuromuscular blocking drug. The priming interval (three minutes) and the priming dose ( $10 \%$ of the total dose) were chosen based on the results of previous studies. ${ }^{5,6,13,14}$

Additional thiopentone $2 \mathrm{mg} \cdot \mathrm{kg}^{-1} \dot{\boldsymbol{i}}$ was given approximately $30 \mathrm{sec}$ before intubation. Tracheal intubation was performed after complete neuromuscular block by an experienced anaesthetist who was not involved in the study and was not aware of the muscle relaxant used. Intubating conditions were scored as "excellent" if the jaw was relaxed, the vocal conds were immobile, and there was no diaphragmatic movement; and "good" if all the 
TABLE I Demographic data

\begin{tabular}{|c|c|c|c|c|c|c|}
\hline Group & $\begin{array}{l}\text { Priming dose } \\
\mathrm{mg} \cdot \mathrm{kg}^{-l}\end{array}$ & $\begin{array}{l}\text { Intubating dose } \\
\mathrm{mg} \cdot \mathrm{kg}^{-I}\end{array}$ & $n$ & $\begin{array}{l}\text { Sex } \\
M / F\end{array}$ & $\begin{array}{l}\text { Age } \\
(y r)\end{array}$ & $\begin{array}{l}\text { Weight } \\
(\mathrm{kg})\end{array}$ \\
\hline I & - & Mivacurium 0.15 & 10 & $6 / 4$ & $31.5(8.2)$ & $72.7(9.5)$ \\
\hline II & Mivacurium 0.015 & Mivacurium 0.135 & 10 & $5 / 5$ & $35.7(10.7)$ & $61.3(10.6)$ \\
\hline III & - & Rocuronium 0.6 & 10 & $3 / 7$ & $31.5(9.5)$ & $66.6(10.2)$ \\
\hline IV & Rocuronium 0.06 & Rocuronium 0.54 & 10 & $6 / 4$ & $30.4(10.5)$ & $72(12.3)$ \\
\hline V & Mivacurium 0.015 & Rocuronium 0.54 & 10 & $7 / 3$ & $28.4(9.9)$ & $72.7(7.9)$ \\
\hline VI & Rocuronium 0.06 & Mivacurium 0.135 & 10 & $6 / 4$ & $33.2(11.7)$ & $62.9(11.5)$ \\
\hline VII & - & Succinylcholine 1.0 & 10 & $7 / 3$ & $35.5(11.1)$ & $70.1(11.1)$ \\
\hline
\end{tabular}

Values are presented as means (SD).

TABLE II Priming sequence, onset time, intubating conditions and recovery of twitch height $\left(\mathrm{T}_{1}\right)$ to $10 \%$ of control tensions

\begin{tabular}{|c|c|c|c|c|c|c|c|c|}
\hline \multirow[b]{2}{*}{ Group } & \multirow{2}{*}{$\begin{array}{l}\text { Priming dase } \\
\mathrm{mg} \cdot \mathrm{kg}^{-1}\end{array}$} & \multirow{2}{*}{$\begin{array}{l}\text { Intubating dose } \\
\mathrm{mg} \cdot \mathrm{kg}^{-1}\end{array}$} & \multirow{2}{*}{$\begin{array}{l}\text { Onset time } \\
\text { (sec) }\end{array}$} & \multicolumn{4}{|c|}{ Intubating conditions } & \multirow{2}{*}{$\begin{array}{l}10 \% \text { recovery } \\
\text { of } T_{l} \text { (min) }\end{array}$} \\
\hline & & & & Excellent & Good & Poor & Inadequate & \\
\hline I & - & Mivacurium 0.15 & $164(141-186) \dagger$ & 6 & 3 & 1 & 0 & $15.3(13.4-17.2)$ \\
\hline II & Mivacurium 0.015 & Mivacurium 0.135 & $103(60-111)$ & 5 & 5 & 0 & 0 & $17.1(14.8-19.3)$ \\
\hline III & - & Rocuronium 0.6 & $90(7 I-109)$ & 7 & 3 & 0 & 0 & $37.5(31.3-43.8) \dagger$ \\
\hline IV & Rocuronium 0.06 & Rocuronium 0.54 & $73(57-90)^{*}$ & 6 & 4 & 0 & 0 & $39(32.2-45.8) \dagger$ \\
\hline V & Mivacurium 0.015 & Rocuronium 0.54 & $58(47-69) *$ & 6 & 4 & 0 & 0 & $36.8(29.6-43.9) \dagger$ \\
\hline VI & Rocuronium 0.06 & Mivacurium 0.135 & $106(87-125)$ & 4 & 6 & 0 & 0 & $18.2(14.7-21.8)$ \\
\hline VII & - & Succinylcholine 1.0 & $54(40-68)^{*}$ & 8 & 2 & 0 & 0 & $8.4(7.6-9.3)^{*}$ \\
\hline
\end{tabular}

Values are presented as means and $95 \%$ confidence intervals.

Onset time is the time from administration of the intubating dose to the development of maximum depression of $\mathrm{T}_{1}$.

"Significantly $(P<0.01)$ shorter from all others.

†Significantly $(P<0.01)$ longer from all others.

above criteria were met except for diaphragmatic movement. Conditions were scored as "poor" if the vocal cords were moving and if there was coughing or bucking; and "inadequate" if, in addition to the above criteria, the jaw clinically was not relaxed. Following intubation, anaesthesia was maintained with $70 \%$ nitrous oxide and $0.5-1 \%$ isoflurane and ventilation was adjusted to maintain normocapnia $\left(\mathrm{PETCO}_{2} 35-40 \mathrm{mmHg}\right.$ ). End-tidal concentrations of $\mathrm{CO}_{2}$ and isoflurane were measured with a multiple-gas analyzer (Capnomac, Datex Instrumentarium Corporation, Helsinki, Finland).

Onset time (time from administration of the intubating dose to the development of maximum depression of $T_{1}$ ) and the time from injection to $10 \%$ recovery of $T_{1}$ were determined. These times were compared with a one-way analysis of variance (ANOVA) and the Student-NewmanKeuls multiple range test. Differences yielding critical values corresponding to $P<0.05$ were considered statistically significant. Intubating conditions were analyzed by Kruskall-Wallis test after assigning a numeric value to each intubation score. All statistical analyses were carried out using BMDP statistical package, release 7.01
(University of California Press, Berkeley, California, 1994). Unless otherwise specified, the results were expressed as means and 95\% confidence intervals.

\section{Results}

Demographic data are shown in Table I. The study groups did not differ in age, sex distribution or weight. The intubating doses resulted in $100 \%$ depression of twitch tension in all, but three patients in Group I. The maximum twitch depression observed in those patients were 96,97 and $98 \%$ of the control tension. Onset times and times to $10 \%$ recovery of $T_{1}$ are summarized in Table II. Onset times in Group IV (priming dose $0.06 \mathrm{mg} \cdot \mathrm{kg}^{-1}$ rocuronium, intubating dose rocuronium $0.54 \mathrm{mg} \cdot \mathrm{kg}^{-1}$ ) and Group V (priming dose $0.015 \mathrm{mg} \cdot \mathrm{kg}^{-1}$ mivacurium, intubating dose $0.54 \mathrm{mg} \cdot \mathrm{kg}^{-1}$ rocuronium) did not differ from those of succinylcholine $1.0 \mathrm{mg} \cdot \mathrm{kg}^{-1}$ (Table II; Figure). Onset times following administration of rocuronium $0.6 \mathrm{mg} \cdot \mathrm{kg}^{-1}$ as a single bolus dose (Group III) or mivacurium in priming sequence (Groups II and VI) were longer than that observed in the aforementioned groups. The onset time of in Group I (who received mivacurium 


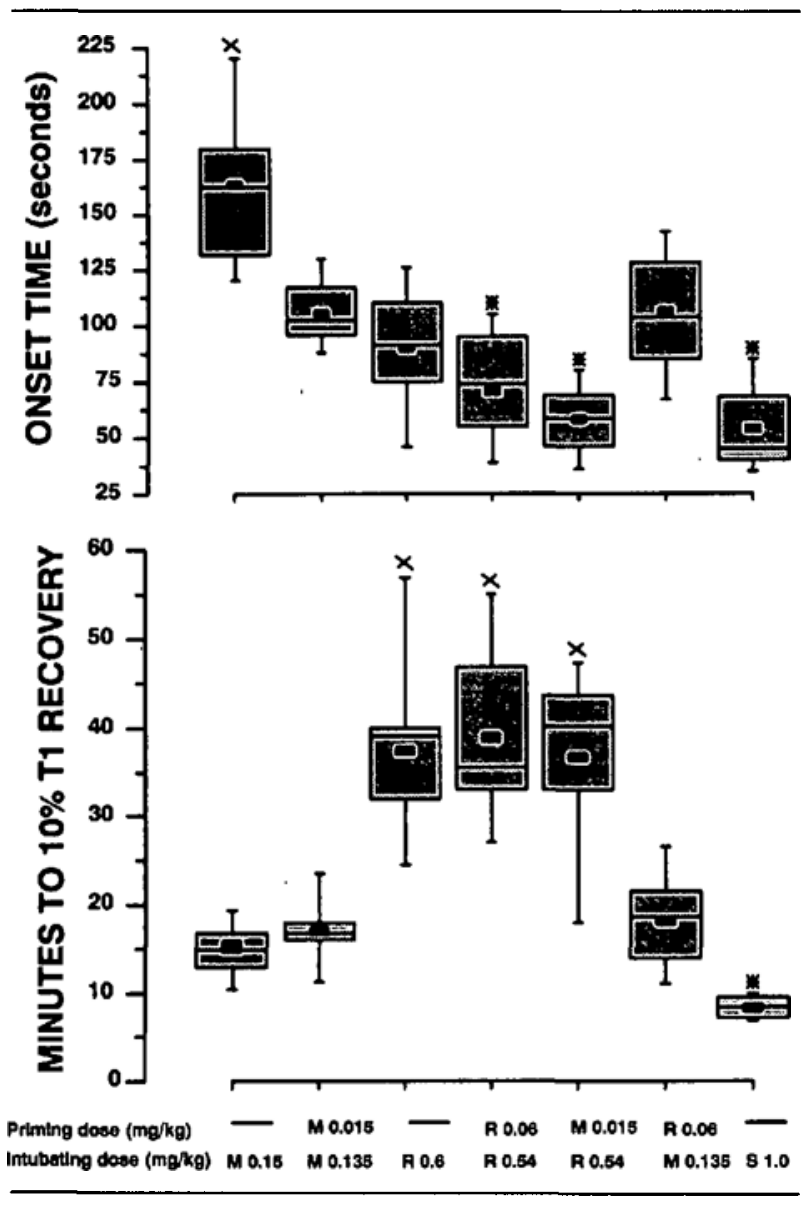

FIGURE Onset time in seconds (upper box chart) and time to $10 \%$ recovery of $T_{1}$ in min (lower box chart). The 25 th to 75 th percentiles are represented by the shaded areas. Medians are shown as horizontal lines within the shaded areas and mark the 50th percentiles. The rectangular symbols in the shaded areas mark the means. Ranges are represented by thet extended bars. $\mathrm{M}=$ Mivacurium. $\mathrm{R}=$

Rocuronium. $S=$ Succinylcholine. ${ }^{*}$ Significantly $(P<0.01)$ shorter from all others. ${ }^{x}$ Significantly $(P<0.01)$ longer from all others.

$0.15 \mathrm{mg} \cdot \mathrm{kg}^{-1}$ as a single bolus dose) was longer $(P<$ 0.01 ) than that in each of the other study groups.

Intubating conditions did not differ in the seven groups (Table II). Times to $10 \%$ recovery of $T_{1}$ were shortest $(P<0.01)$ in the succinylcholine group, and longest $(P$ $<0.01$ ) in Groups III, IV and V (Table II; Figure). Priming a mivacurium block with mivacurium or rocuronium, or priming a rocuronium block with rocuronium or mivacurium did not affect the duration of action of mivacurium or rocuronium, respectively.

\section{Discussion}

The results of this study indicate that administration of a priming dose of rocuronium $0.06 \mathrm{mg} \cdot \mathrm{kg}^{-1}$ or of mivacurium $0.015 \mathrm{mg} \cdot \mathrm{kg}^{-1}$ followed three minutes later by an intubating dose of rocuronium $0.54 \mathrm{mg} \cdot \mathrm{kg}^{-1} \mathrm{re}-$ sults in a neuromuscular block that resembles succinylcholine $1.0 \mathrm{mg} \cdot \mathrm{kg}^{-1}$ in both the onset of action and intubating conditions. In this study we used the standard intubating doses of all drugs studied. It should be noted, however, that the dose of succinylcholine used in this study $\left(1.0 \mathrm{mg} \cdot \mathrm{kg}^{-1}, 3 \times \mathrm{ED}_{95}\right)^{15}$ is larger than that of rocuronium $\left(0.6 \mathrm{mg} \cdot \mathrm{kg}^{-1}, 2 \times \mathrm{ED}_{95}\right)^{7,16}$ or mivacurium $\left(0.15 \mathrm{mg} \cdot \mathrm{kg}^{-1}, 2 \times \mathrm{ED}_{95}\right)^{7,17}$ The total doses administered to Groups I-VI were equipotent.

In the analysis of the onset time of rocuronium and mivacurium with and without priming, it is important to make comparisons with those of succinylcholine. Despite its rapid onset of action, ${ }^{12}$ we noted in this study that the mean time to maximum block of $90 \mathrm{sec}$ following administration of a single bolus dose rocuronium 0.6 $\mathrm{mg} \cdot \mathrm{kg}^{-1}$ was longer $(P<0.01)$ than a mean time of $54 \mathrm{sec}$ with succinylcholine $1.0 \mathrm{mg} \cdot \mathrm{kg}^{-1}$. Our results agree with those of others. ${ }^{2,18}$ Cooper et al ${ }^{18}$ reported onset times of 60.4 (22.4) and 88.9 (36.9) sec (mean (SD)), respectively, after succinylcholine $1.0 \mathrm{mg} \cdot \mathrm{kg}^{-1}$ and rocuronium $0.6 \mathrm{mg} \cdot \mathrm{kg}^{-1}$ in patients anaesthetized with thiopentone, fentanyl and nitrous oxide in oxygen. Similarly, Magorian et al. ${ }^{2}$ reported onset times of 50 (17) and 89 (33) sec (mean (SD)) after succinylcholine 1.0 $\mathrm{mg} \cdot \mathrm{kg}^{-1}$ and rocuronium $0.6 \mathrm{mg} \cdot \mathrm{kg}^{-1}$, respectively.

In this study, we demonstrated that the priming technique can accelerate the onset time of rocuronium further and makes it comparable with that of succinylcholine (Table II; Figure). Using the priming technique with rocuronium in anaesthetized rats, Foldes et al. ${ }^{19}$ reported that the onset time of $1.15 \times \mathrm{ED}_{90}$ of rocuronium, 16.3 (3.2) (mean (SEM)), decreased to $10(0.8)$ and $9.6(1.0)$ sec $(P<0.01)$ respectively, when rocuronium was administered one minute after priming with $0.25 \times \mathrm{ED}_{90}$ $\mathrm{d}$-tubocurarine or vecuronium, $0.85 \times \mathrm{ED}_{90}$. The same group, however, reported that administration of a 0.1 $\mathrm{mg} \cdot \mathrm{kg}^{-1}$ priming dose of rocuronium followed by an $0.5 \mathrm{mg} \cdot \mathrm{kg}^{-1}$ intubating dose four minutes later in man did not result in any acceleration in the onset time. ${ }^{20}$ This difference in results could be attributed to the difference in the size of the priming doses $\left(0.1 \mathrm{mg} \cdot \mathrm{kg}^{-1}\right.$ vs $0.06 \mathrm{mg} \cdot \mathrm{kg}^{-1}$ in this study) and priming intervals (four vs three minutes in this study). A priming interval of four minutes may be too long for a rapid-acting drug like rocuronium.

We have demonstrated that mixtures of rocuronium and mivacurium are synergistic in humans. ${ }^{7}$ The calculated $\mathrm{ED}_{50}$ of rocuronium and mivacurium mixture was only $62 \%$ of the predicted value assuming a purely additive interaction. ${ }^{7}$ In this study, priming a rocuronium with rocuronium (Group IV) shortens the onset time by approximately 20\% (from 90 to $73 \mathrm{sec}$; Table II; Figure), whereas in Group V, priming with mivacurium produced 
a greater reduction (approximately $35 \%$ ) in the onset time (from $90 \mathrm{sec}$ to $58 \mathrm{sec}$ ). The results of this study also indicate that using the priming technique with mivacurium (Groups II and VI) does shorten the onset time by approximately $40 \%$ (from 164 to slightly over 100 sec; Table II; Figure). Nevertheless, the acceleration in the onset time was not of sufficient magnitude to approximate that of succinylcholine (Table II; Figure). In agreement with our results, Molbegott and Baker ${ }^{21}$ reported that the onset time of a bolus dose of mivacurium $0.15 \mathrm{mg} \cdot \mathrm{kg}^{-1}$ was reduced from $169.9(7.8) \mathrm{sec}$ to 99.6 (6.7) sec (mean (SEM)) following a priming sequence (priming dose of $0.015 \mathrm{mg} \cdot \mathrm{kg}^{-1}$ followed five minutes later by an intubating dose of $0.135 \mathrm{mg} \cdot \mathrm{kg}^{-1}$ ). They also noted that, only by increasing the intubating dose of mivacurium to $0.2 \mathrm{mg} \cdot \mathrm{kg}^{-1}$ (a total dose of 0.21 $\mathrm{mg} \cdot \mathrm{kg}^{-1}$ ), did the onset time of mivacurium approximate that of succinylcholine $1.0 \mathrm{mg} \cdot \mathrm{kg}^{-1}(81.9$ (2.7) $\mathrm{sec}$ and 82.9 (3.5) sec, respectively). ${ }^{21}$

As reviewed in the introduction, intubating conditions depend on many factors, and depth of anaesthesia is a fundamental component contributing to the adequacy of the intubating conditions. In this study, a supplemental dose of thiopentone $2 \mathrm{mg} \cdot \mathrm{kg}^{-1}$ was administered before the injection of the intubating dose. We noted earlier that such a technique can result in better conditions for tracheal intubation. ${ }^{10}$ That the intubating conditions did not differ among the seven groups studied (Table II) emphasizes the importance of this technique. The results of this study also indicate that, after priming, rocuronium resembles succinylcholine in producing good-to-excellent intubating conditions in approximately $60 \mathrm{sec}$. The intubating conditions of rocuronium and succinylcholine described in this study were similar to those reported by others. ${ }^{2,18}$ Cooper et al. ${ }^{18}$ found that the intubating conditions after rocuronium $0.6 \mathrm{mg} \cdot \mathrm{kg}^{-1}$ to be clinically acceptable (good or excellent) in $95 \%$ of patients at 60 $\mathrm{sec}$ and in all patients at $90 \mathrm{sec}$ and in all patients at both times after succinylcholine $1.0 \mathrm{mg} \cdot \mathrm{kg}^{-1}$. As reported in their study, ${ }^{18}$ the degree of neuromuscular block at the time of tracheal intubation with rocuronium was 89 (SD 15.5)\% at $60 \mathrm{sec}$ and $98(3.0) \%$ at $90 \mathrm{sec}$. Magorian et al., ${ }^{2}$ using a different protocol, reported excellent intubating conditions in $100 \%$ of their patients after rocuronium $0.6 \mathrm{mg} \cdot \mathrm{kg}^{-1}$.

Differences in neuromuscular blocking potency and in the rate of block development between the skeletal muscle and the vocal cords with other muscle relaxants have been reported both in animal and humans. ${ }^{9,22-24}$ Donati et al. ${ }^{22}$ were able to demonstrate with vecuronium more rapid onset of block on the vocal cords than on the adductor pollicis muscle in anaesthetized patients. In another study, ${ }^{23}$ they reported that rocuronium had a faster onset at both muscles than vecuronium. The reason for this rapid onset could be attributed to potency ${ }^{25}$ and/ or different buffering ${ }^{26}$ (i.e., the repetitive binding of relaxant molecules) of muscle relaxants.

In the current study, times to $10 \%$ recovery of $T_{1}$ for the same total dose of mivacurium or rocuronium were not influenced by priming with the equipotent doses of either drug (Table II). This observation is in agreement with the results of other studies. $5,10,13$

In conclusion, this study demonstrates that priming with rocuronium $0.06 \mathrm{mg} \cdot \mathrm{kg}^{-1}$ or mivacurium 0.015 $\mathrm{mg} \cdot \mathrm{kg}^{-1}$ followed three minutes later by rocuronium $0.54 \mathrm{mg} \cdot \mathrm{kg}^{-1}$ resulted in a neuromuscular block which was similar to that of succinylcholine $1.0 \mathrm{mg} \cdot \mathrm{kg}^{-1}$ in both the onset of action and intubating conditions. This study also illustrates that the priming technique can reduce the onset time of both mivacurium (by approximately $40 \%$ ) and rocuronium (by approximately 20-35\%). Priming with alternative drug does not seem to offer advantages.

\section{References}

1 Rórvik K, Husby P, Gramstad L, Vamnes JS, BitschLarsen $L$, Koller $M-E$. Comparison of large dose of vecuronium with pancuronium for prolonged neuromuscular blockade. Br J Anaesth 1988; 61: 180-5.

2 Magorian T, Flannery $K B$, Miller RD. Comparison of rocuronium, succinylcholine, and vecuronium for rapidsequence induction of anesthesia in adult patients. Anesthesiology 1993; 79: 913-8.

3 Gibbs NM, Rung GW, Braunegg PW, Martin DE. The onset and duration of neuromuscular blockade using combinations of atracurium and vecuronium. Anaesth Intensive Care 1991; 19: 96-100.

4 Doherty WG, Breen PJ, Donati F, Bevan DR. Accelerated onset of pancuronium with divided doses. Can Anaesth Soc J 1985; 32: 1-4.

5 Naguib M, Gyasi HK, Abdulatif M, Absood GH. Rapid tracheal intubation with atracurium - a comparison of priming intervals. Can Anaesth Soc J 1986; 33: 150-6.

6 Taboada JA, Rupp SM, Miller RD. Refining the priming principle for vecuronium during rapid-sequence induction of anaesthesia. Anesthesiology 1986; 64: 243-7.

7 Naguib $M$. Neuromuscular effects of rocuronium bromide and mivacurium chloride administered alone and in combination. Anesthesiology (in press).

8 Baumgarten RK, Carter CE, Reynolds WJ, Brown JL, DeVera $H V$. Priming with nondepolarizing relaxants for rapid tracheal intubation: a double-blind evaluation. Can J Anaesth 1988; 35: 5-11.

9 Meistelman C, Plaud B, Donati F. Neuromuscular effects of succinylcholine on the vocal conds and adductor pollicis muscles. Anesth Analg 1991; 73: 278-82. 
10 Naguib $M$, Abdulatif $M$, Gyasi $H D$, Absood GH. Priming with atracurium: improving intubating conditions with additional doses of thiopental. Anesth Analg 1986; 65: 1295-9.

11 Savarese JJ, Ali HH, Basta SJ, et al. The clinical neuromuscular pharmacology of mivacurium chloride (BW B1090U). A short-acting, nondepolarizing ester neuromuscular blocking drug. Anesthesiology 1988; 68: 723-32.

12 Bartkowski RR, Witkowski TA, Azad S, Lessin J, Marr A Rocuronium onset of action: a comparison with atracurium and vecuronium. Anesth Analg 1993; 77: 574-8.

13 Naguib $M$, Abdulatif $M$, Absood $G H$. The optimal priming dose for atracurium. Can Anaesth Soc J 1986; 33: 453-7.

14 Peterman $R$, Axelrod E, Brown $M$. Rapid sequence induction with mivacurium. Anesthesiology 1993; 79: A937.

15 Smith CE, Donati F, Bevan DR. Dose-response curves for succinylcholine: single versus cumulative techniques. Anesthesiology 1988; 69: 338-42.

16 Cooper R, Mirakhur RK, Elliott P, McCarthy GJ. Estimation of the potency of ORG 9426 using two different modes of nerve stimulation. Can J Anaesth 1992; 39: 139-42.

17 Caldwell JE, Kitts JB, Heier T, Fahey MR, Lynam DP, Miller $R D$. The dose-response relationship of mivacurium chloride in humans during nitrous oxide-fentanyl or nitrous oxide-enflurane anesthesia. Anesthesiology 1989; 70: 31-5.

18 Cooper R, Mirakhur RK, Clarke RSJ, Boules Z. Comparison of intubating conditions after administration of ORG 9426 (rocuronium) and suxamethonium. $\mathrm{Br} \mathbf{J}$ Anaesth 1992; 69: 269-73.

19 Foldes FF, Nagashima $H$, Kornak PH. Effect of priming. Anaesthetic Pharmacology Review 1993; 1: 49-56.

20 Foldes FF, Nagashima H, Nguyen HD, Schiller WS, Mason MM, Ohta $Y$. The neuromuscular effects of ORG9426 in patients receiving balanced anesthesia. Anesthesiology 1991; 75: 191-6.

21 Molbegott L, Baker T. Speed and ease of endotracheal intubation after mivacurium doses of various multiples of ED95 with and without priming compared to SCH. Anesthesiology 1993; 79: A933.

22 Donati F, Meistelman C, Plaud B. Vecuronium neuromuscular blockade at the adductor muscles of the larynx and adductor pollicis. Anesthesiology 1991; 74: 833-7.

23 Meistelman C, Plaud B, Donati F. Rocuronium (ORG 9426) neuromuscular blockade at the adductor muscles of the larynx and adductor pollicis in humans. Can J Anaesth 1992; 39: 665-9.

24 Vandenbrom RHG, Houwertjes MC, Agoston S. A method for studying the pharmacodynamic profile of neuromuscular blocking agents on vocal cord movements in anaesthetized cats. Br J Pharmacol 1991; 102: 861-4.

25 Donati F, Meistelman C. A kinetic-dynamic model to ex- plain the relationship between high potency and slow onset time for neuromuscular blocking drugs. J Pharmacokinet Biopharm 1991; 19: 537-52.

26 Glavinovic MI, Law Min JC, Kapural L, Donati F, Bevan $D R$. Speed of action of various muscle relaxants at the neuromuscular junction binding vs buffering hypothesis. $J$ Pharmacol Exp Ther 1993; 265: 1181-6. 